\title{
"Will a Black Hole Eventually Swallow the Earth?" Fifth Graders' Interest in Questions from a Textbook, an Open Educational Resource, and Other Students' Questions
}

\author{
Hani Swirski \& Ayelet Baram-Tsabari \\ Faculty of Education in Science and Technology \\ Technion - Israel Institute of Technology, Haifa, Israel \\ hanis@tx.technion.ac.il ayelet@technion.ac.il
}

\begin{abstract}
Can questions sent to Open-Educational-Resource (OER) websites such as Ask-An-Expert serve as indicators for students' interest in science? This issue was examined using an online questionnaire which included an equal number of questions about the topics "space" and "nutrition" randomly selected from three different sources: a 5th-grade science textbook, the "Ask-An-Expert" website, and questions collected from other students in the same age group. A sample of 113 5thgraders from two elementary schools were asked to rate their interest level in finding out the answer to these questions without knowledge of their source. Significant differences in students' interest level were found between questions: textbook questions were ranked lowest for both subjects, and questions from the open-resource were ranked high. This finding suggests that questions sent to an open-resource could be used as an indicator of students' interest in science. In addition, the high correlation of interests expressed by students from the two schools may point to a potential generalization of the findings. This study contributes by highlighting OER as a new and promising indicator of student interest, which may help bring "student voices" into mainstream science teaching to increase student interest in science.
\end{abstract}

Keywords: Ask-A-Scientist, elementary school, Interest, Open Educational Resource, Science curriculum, Students' questions, Student voice.

\section{Introduction}

Material published as part of this publication, either on-line or in print, is copyrighted by the Informing Science Institute. Permission to make digital or paper copy of part or all of these works for personal or classroom use is granted without fee provided that the copies are not made or distributed for profit or commercial advantage AND that copies 1) bear this notice in full and 2) give the full citation on the first page. It is permissible to abstract these works so long as credit is given. To copy in all other cases or to republish or to post on a server or to redistribute to lists requires specific permission and payment of a fee. Contact Publisher@InformingScience.org to request redistribution permission.
The notion of "student voice", which refers to learning based on student choices and interests ("Student voice," 2013), was introduced in the late $20^{\text {th }}$ century in Dewey's work $(1902,1916)$. He saw interest as a crucial factor in learning. Today, however researchers are still drawing attention to the lack of a "student voice" in teaching and learning (Cook-Sather, 2006).

\section{Editor: Janice Whatley}

An earlier, shorter version of this paper was presented at the Chais conference 2015, in Raanana, Israel, and included in Y. Eshet-Alkalai, I. Blau, A. Caspi, N. Geri, Y. Kalman, \& V. Silber-Varod (Eds.), Proceedings of the 10th Chais Conference for the Study of Innovation and Learning Technologies 2015: Learning in the Technological Era. Raanana: The Open University of Israel. 
To promote the "student voice" in science education, Hagay and Baram-Tsabari (2011) suggested the implementation of a "shadow curriculum" - a strategy for identifying students' interests based on their questions and incorporating them into the formal curriculum in a planned manner. While the strategy supports students' intrinsic motivations, it requires considerable work from the teacher to collect and research student questions (Hagay \& Baram-Tsabari, 2015). Creating an online repertoire of interesting Q\&A and their curricular relevance ("an online shadow curriculum") may help remedy this problem, and pave the way for better inclusion of students' interests in mainstream teaching.

Clearly, creating a unique repertoire for every teacher is impossible. Thus, the online shadow curriculum would only be applicable if students share similar interests in science questions. Initial indications of the generalizability of students' science interests across countries and religions were presented in Hagay et al. (2013). They found that students from Portugal, Turkey, England, and Israel, show interest in similar science questions.

It is important to note that the questions examined in the above-mentioned study were originally raised by students. However, since students' questions asked openly in class are quite rare (Dillon, 1988), there is a need for another source of interesting questions. One possible source might be questions sent to a free-choice environment, such as a TV shows and an Ask-a-scientist websites, in which "people usually ask questions to obtain information that they are lacking, rather than posing rhetorical questions, suggestive questions, or questions asked to please someone" (Baram-Tsabari, 2015 p.150).

Thus in order to produce an applicable "online shadow curriculum", this study was designed to examine the validity of using questions sent to an Open-Educational-Resource (OER) as indicators of student interest. Specifically, it focused on the Ask-An-Expert website, which is a section of an informal science institute's website.

We also compared students' interest in science questions at three distance levels from the "student voice": Students' interest level in (1) questions collected from other students in the same age group, (2) questions sent by motivated surfers of the OER, and (3) questions taken from the $5^{\text {th }}$-grade science textbook, which covers the science curriculum.

Following is a theoretical background of the concept "student voice" and the field of OERs, drawing potential connections between the two and setting the scene for the research goals.

\section{Literature Review and Conceptual Framework}

\section{"Student Voice" and Interest in Science Learning}

"Student voice" refers to the values, opinions, beliefs, and perspectives of individual students and groups of students in school. It also refers to learning that is based on student choices and interests ("Student voice," 2013). Recent studies have indicated the potential of incorporating students' voice into decision making on different aspects of school life (e.g., Davie \& Galloway, 1996; Hennessy, 1999). According to Jenkins (2006, p. 51), "Involving students in decisions about their education can be regarded as a means of introducing them to the complexities and limitations of the democratic process and thus as something of a preparation for their future role as citizens".

Beyond the experience with the democratic process, the "student voice" may also be effective in improving teaching, the curriculum, and teacher-student relationships (Mitra, 2004). "Students have unique knowledge and perspective...By talking with and listening to students, we can learn more about how classroom and school processes can be made powerful, and how improvement can be fostered..." (Levin, 2000, p. 158). 
However, according to Cook-Sather (2006, p. 359) “...despite its increasing and emphatic use, none such clear and definite conception exists for 'student voice'." More specifically, in science education Jenkins (2006) identified a variety of meanings using this term. For some, the student voice refers to "students view about the form, content and purpose of their school science education", while for others, it refers to exploring "students' attitudes towards a variety of sciencerelated issues and whether or not they wish to pursue a career in science or technology" (Jenkins, 2006, p. 50).

Moreover, there is a mix between pedagogical and content implications. Over the last decade, many studies have examined the effect of "student voice" on learning mostly from pedagogical perspectives and have interpreted the "student voice" in a student-centered context (e.g., Mitra, 2003; Toshalis \& Nakkula, 2012). While the idea of student-centered pedagogy has been widely accepted (Kain, 2003), the content aspect of the "student voice" has been less well examined or related to pedagogy. Counter examples are fairly rare; for example, in Grace (1999) first and second graders chose the learning subject and the learning process. Murray and Reiss (2005) examined student reviews of the science curriculum in England. The survey included questions on the science curriculum content (e.g., "Is it right to include controversial issues such as genetic engineering or cloning in the science syllabus?") and questions on pedagogy in science education (e.g., "Which three of these methods of teaching and learning do you find the most useful and effective in helping understand your school science?").

Listening to the "student voice" with regard to content may contribute to increasing students' interest level (Hagay \& Baram-Tsabari, 2011). Interest is a critical cognitive motivational variable that facilitates learning in different content areas and in all age groups (Renninger \& Hidi, 2011). It also has a strong influence on students' cognitive functioning (Ainley, Hidi, \& Berndorff, 2002) and learning outcomes (Swarat, Ortony, \& Revelle, 2012). Specifically, within the elective field of advanced science education, students' interest level has been found to explain and predict their career choice (e.g., Tai, Liu, Maltese, \& Fan, 2006; Xie \& Reider, 2014).

\section{How should interest be measured?}

Renninger and Hidi (2011) reviewed a number of acceptable methods for measuring interest. One is self-report measures, which require participants to rate their interest level on given items using a questionnaire or survey. This method is very popular in studies on interest evaluation (Frenzel et al., 2009, as cited in Renninger \& Hidi, 2011). However, the items in this method are chosen by the researcher and therefore are limited in their scope and relevance.

Another possible indicator of student interest is student questions (e.g., Baram-Tsabari \& Yarden, 2005; Chin \& Osborne, 2008; Hagay \& Baram-Tsabari, 2011; Jidesjö, Oscarsson, Karlsson, \& Strömdahl, 2009). When students raise questions, they express scientific concepts in their own words using their prior knowledge (Baram-Tsabari \& Yarden, 2007). One of the advantages of this approach over questionnaires is students' ability to express their interests, rather than respond to a list suggested by a researcher.

In this study, we employed the two approaches to measure student interest. The first was students' questions, which were viewed and used as expressions of "student voice". The second was self-reporting questionnaires, which were used to evaluate students' interest in science questions.

\section{Open Educational Resources}

Open Educational Resources (OER) are "digitized materials offered freely and openly for educators, students and self-learners to use and re-use for teaching, learning and research" (Hylén, 2006, p. 49). For example, course materials, textbooks, streaming videos, multimedia applica- 
tions, and any other material designed for usage in teaching and learning are included in the definition of OER (Kanwar, Uvalić-Trumbić, \& Butcher, 2011).

Weller (2010, p. 2) differentiated between two types of OERs: "Big OERs... are usually of high quality, contain explicit teaching aims, presented in a uniform style and form part of a timelimited, focused project with portal and associated research and data. Little OERs are the individually produced, low cost resources. They are produced by anyone, not just educators, may not have explicit educational aims, have low production quality and are shared through a range of third party sites and services."

There has been extensive research on the contribution of OERs to education over the last decade. Some studies have dealt with models for using OERs (e.g. Hilton, Wiley, \& Johnson, 2010; Wiley, 2009). These have specifically focused on teachers using OERs (e.g., Cohen, Kalimi, \& Nachmias, 2013) and on their training needs (e.g., Clements \& Pawlowski, 2012). Other studies have examined the characters of OER users and providers and have looked at what prompts individuals to share their digital resources (e.g. Hylén, 2006).

One form of OERs that has attracted quite a bit of research attention is question and answer (Q\&A) websites. According to Harper, Raban, Rafaeli, and Konstan (2008, p. 866) Q\&A websites are "places where users ask questions and others answer them". They identified three types of commonly used Q\&A sites:

1. Digital reference services, such as the New York Public Library's "Ask Librarians online" (http://www.nypl.org/ask-nypl/about). This type of website can be classified as a Big OER in which trained information specialists answer user questions.

2. Community Q\&A sites, such as Yahoo! Answers (https://answers.yahoo.com/), which is the most frequently visited community Q\&A website in the United States (Harper et al., 2008). This type of website can be classified as a Little OER in which everyday users answer other users' questions.

3. Ask-An-Expert services, such as "Ask-Our-Experts" website (http://davidson.weizmann.ac.il/en/online/askexpert), which is part of the Davidson Institute of Science Education website. The consideration of this site as an OER is further supported by a license from the Israeli Ministry of Education ensuring the site is a suitable content provider for secondary school science teachers (Israeli Ministry of Education, 2015). This type of website falls into the category of Big OERs in which scientists answer users' questions.

This latter type of Q\&A, which is examined in this study, tends to be topic-oriented (Harper et al., 2008). Thus, in an educational context, it could serve as a free-choice learning environment for a specific discipline and provide data on individual needs and interests in a natural setting (BaramTsabari, Sethi, Bry, \& Yarden, 2006). This approach is unique in that it can tap OERs not as a learning resource but as an interest identification resource and, thus, can act as an indicator of students' interests, which could help incorporate the "student voice" into mainstream science teaching.

\section{Research Goal and Questions}

This study examined the differences in $5^{\text {th }}$ graders' interests in questions from three sources, each of which represents a different distance level from the "student voice": (1) Questions asked by $5^{\text {th }}$ graders from other schools (which represent other students' questions), (2) OER questions (which represent other people's questions), and (3) Science textbook questions (which represent the science curriculum). 
Specifically, we explored the following:

1. What are the differences in students' interest level in questions from these three resources?

2. To what extent will there be commonalities between students' interests in these two different schools?

\section{Methodology}

\section{Participants}

The study involved 113 (56 females, 57 males) $5^{\text {th }}$ graders (10-11 years old) from two public elementary schools (two classes in each) in the northern part of Israel. The schools were chosen for their accessibility and their agreement to take part in this research.

These schools are characterized by an average socio-economic level, according to the latest socioeconomic report of the local authorities (Israel Ministry of Finance, 2008).

According to a national assessment conducted by the Israeli Ministry of Education \& RAMA (http://cms.education.gov.il/EducationCMS/Applications/IMS/HomePage.htm) in 2012 and 2013, the two schools are characterized by a below-average level of student attitude toward science compared to public schools with the same socio-economic level. (A copy of the questionnaire [in Hebrew] can be found at http://meyda.education.gov.il/files/Rama/25-mad-012-5A-SOF-net.pdf) In addition, the two schools are characterized by an above-average level of academic achievement, with school B ranked 5 points higher (on a scale of 100) than school A (Table 1).

Table 1: Participating schools' statistics in relation to science education

\begin{tabular}{|c|c|c|c|}
\hline & $\begin{array}{c}\text { School A } \\
(n=66)\end{array}$ & $\begin{array}{l}\text { School B } \\
(n=47)\end{array}$ & National average \\
\hline $\begin{array}{l}\text { Average academic achievements on a national science and } \\
\text { technology test }\end{array}$ & 61 & 66 & 55 \\
\hline $\begin{array}{l}\text { Students' self-reports about competence in science. Measured } \\
\text { by agreement with the statement: "Usually I do well in science } \\
\text { and technology". }\end{array}$ & $74 \%$ & $85 \%$ & $72 \%$ \\
\hline $\begin{array}{l}\text { Students' self-reports about enjoyment in learning science. } \\
\text { Measured by agreement with the statement: "I enjoy learning } \\
\text { science and technology". }\end{array}$ & $60 \%$ & $34 \%$ & $72 \%$ \\
\hline $\begin{array}{l}\text { Students' self-reports concerning the value and importance of } \\
\text { learning science. Measured by agreement with the statement: } \\
\text { "It is important for me to study science and technology". }\end{array}$ & $81 \%$ & $81 \%$ & $84 \%$ \\
\hline \multicolumn{4}{|c|}{$\begin{array}{l}\text { The data are based on the report of Israeli Ministry of Education \& RAMA - The National Authority for Measurement and } \\
\text { Evaluation in Education (2012; 2013). } \\
\text { Agreement with the statements was measured on a Likert scale with } 1 \text { (highly disagree) to } 5 \text { (highly agree). } \\
\text { The numbers represent the percentage of students who marked the two higher values ( } 4 \text { or } 5 \text { ). } \\
\text { "Science and technology" refers to science classes. }\end{array}$} \\
\hline
\end{tabular}

\section{Research Tool: Questionnaire}

To assess students' interests, a questionnaire was developed. The online questionnaire was administered in both schools during one of the final science lessons of the school year after completing the curriculum. It required about 15 minutes to complete. For ethical reasons, the questionnaires were anonymous, and students were asked only to state their gender. 
The questionnaire was composed of 42 questions. Students were asked to rank their interest in getting the answer to each question on a 1 (very interested) to 5 (not interested at all) Likert scale (Figure 1).

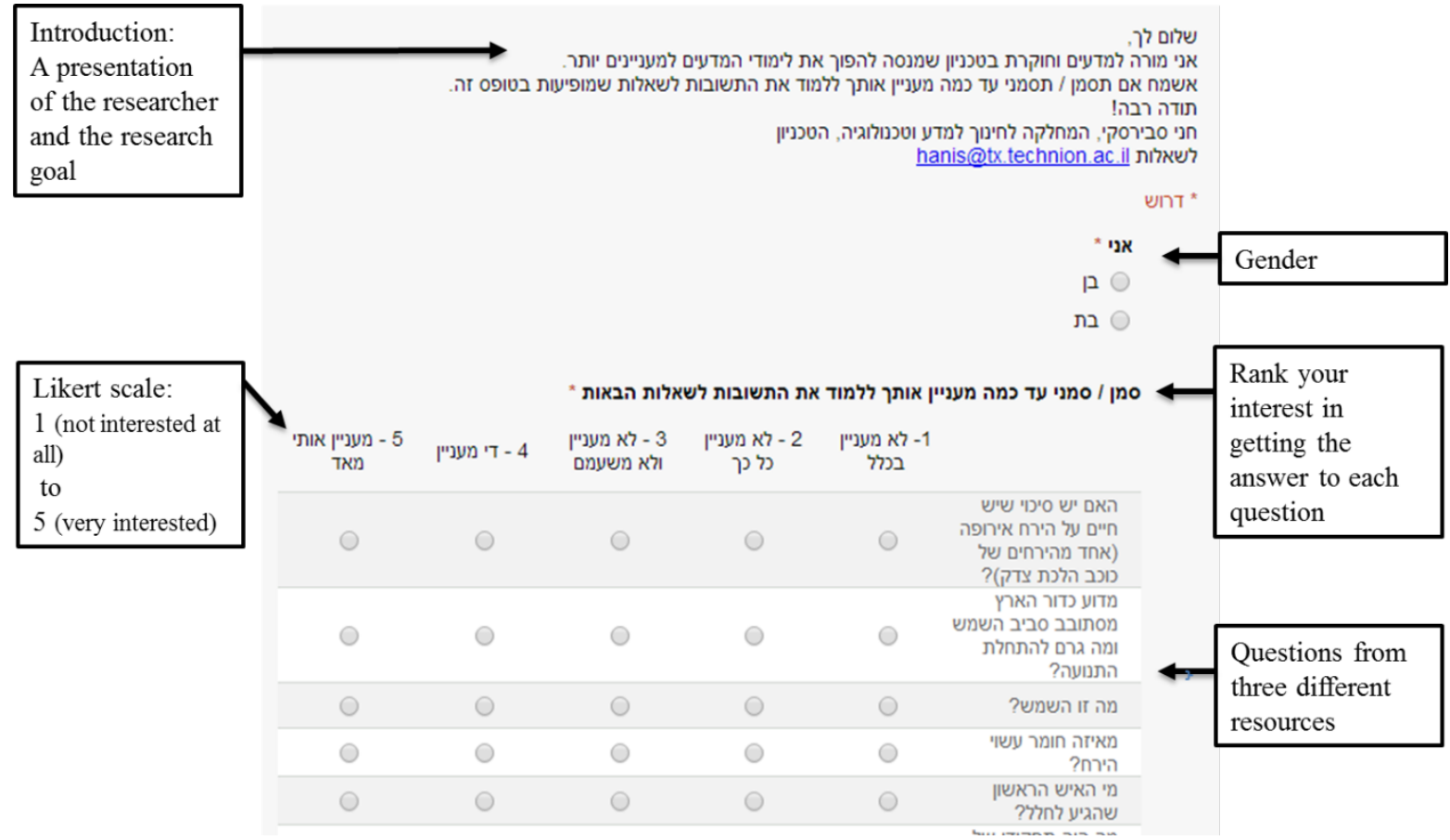

Figure 1: The online questionnaire

Twenty-one of the questions were on the topic of "space" and the other 21 concerned "nutrition". These topics are two out of the three on the $5^{\text {th }}$-grade science curriculum and are also included in the "Ask-Our-Experts" website (unlike the third topic, "natural resources", which is not).

The 21 questions on each topic were randomly selected from three sources (seven questions from each):

1. Textbook: The "Science and Technology" textbook for the $5^{\text {th }}$ grade (Center for Science and Technology, 2008) is commonly used in elementary schools including the two participating schools. The textbook was approved by the Israeli Ministry of Education in 2008. It is based on the Science, Technology, and Society (STS) approach, which combines several scientific fields and emphasizes the relevance of the science content to students' everyday life. The textbook covers three topics: "space", "nutrition" and "natural resources", according to $5^{\text {th }}$-grade science curriculum. There are about 60 questions for each topic presented throughout the chapter.

2. Open-Educational-Resource: The "Ask-Our-Experts" section, "Davidson online", the website of The Davidson Institute Of Science Education - the educational wing of the Weizmann Institute of Science (http://davidson.weizmann.ac.il/online/askexpert). The section was first established in 2005 and has almost 3000 Q\&As. The Q\&As are classified by scientific field, such as Medicine, Chemistry, Physics, Earth Science and Technology. Questions are answered by graduate students in the sciences.

3. Students' Questions: A total of 310 questions addressing the topic "nutrition", and 341 questions addressing the topic "space" were anonymously collected from $5^{\text {th }}$ grade stu- 
dents from two additional schools. The questions were collected in 2013 using written prompts in a similar process to the collection process described in Swirski and BaramTsabari (2014, p. 157).

\section{Questionnaire Development Process}

The questionnaire development process had four stages (Figure 2).

Stage 1: Filtering procedure. Omitting textbook questions that depended on external content (e.g., text and figures) and selecting open-resource questions compatible with the students' age. Repetitive questions were left in, thus increasing the likelihood they would be chosen in the random sampling. All anonymously collected questions from $5^{\text {th }}$ grade students in two additional schools were used.

Stage 2: Inter-coder reliability for filtering of questions. In order to establish inter-coder reliability, the textbook questions and the open-resource questions were also filtered by an elementary school science teacher and yielded substantial agreement (80\%).

Stage 3: Selection. All the questions from each source were numbered separately. Seven questions from each source for each topic were randomly selected using the Excel RAND() function.

Stage 4: Randomly ordering the questions.

The Cronbach alphas indicated high reliability (internal consistency) for all 14 questions from the same source $\left(\alpha_{\text {textbook }}=0.926, \alpha_{\text {open-resource }}=0.91\right.$ and $\left.\alpha_{\text {student-questions }}=0.906\right)$.

\begin{tabular}{|l|l|l|l|}
\hline \multicolumn{1}{|c|}{ Question Source } & \multicolumn{1}{|c|}{$\mathbf{5}^{\text {th }}$ grade Textbook } & \multicolumn{1}{c|}{$\begin{array}{c}\text { Open Educational } \\
\text { Resource }\end{array}$} & \multicolumn{1}{|c|}{$\mathbf{5}^{\text {th }}$ grade Students } \\
\hline $\begin{array}{l}\text { Nutrition } \\
\text { (number of questions) }\end{array}$ & $\begin{array}{l}\text { Original number: } 72 \\
\text { After filtering: } 37\end{array}$ & $\begin{array}{l}\text { Original number: } 82 \\
\text { After filtering: } 45\end{array}$ & 310 \\
\hline $\begin{array}{l}\text { Space } \\
\text { (number of questions ) }\end{array}$ & $\begin{array}{l}\text { Original number: } 50 \\
\text { After filtering: } 40\end{array}$ & $\begin{array}{l}\text { Original number: } 155 \\
\text { After filtering: } 85\end{array}$ & 341 \\
\hline
\end{tabular}

Inter-coder reliability for filtering of questions: above $80 \%$ agreement for all samples
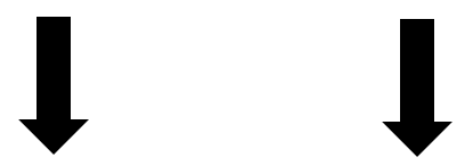

Randomly selecting seven questions from each source for each topic

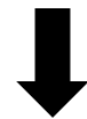

Randomly ordering the questions

Figure 2: The questionnaire development process

\section{Data Analysis}

To assess students' interest level in questions from the three resources, we defined six new independent variables. Each variable represents the average interest level of seven questions on the same topic and from the same source (Table 2). For example, all the questions from the textbook 
about "space" were defined as one variable, the questions from the textbook about "nutrition" defined as a second variable, etc. In addition, "gender" (F/M) and "school" (A/B) were defined as discrete variables.

Table 2: Variable construction. Each variable included questions from the same source on the same topic

\begin{tabular}{|l|l|l|l|}
\hline \multicolumn{1}{|c|}{ Question source } & \multicolumn{1}{|c|}{$\mathbf{5}^{\text {th }}$ grade Textbook } & Open Educational Resource & $\mathbf{5}^{\text {th }}$ grade Students \\
\hline $\begin{array}{l}\text { Nutrition } \\
\text { (question numbers) }\end{array}$ & $24,26,27,28,33,39,41$ & $25,30,31,34,35,36,37$ & $22,23,29,32,38,40,42$ \\
\hline $\begin{array}{l}\text { Space } \\
\text { (question numbers) }\end{array}$ & $6,7,10,11,16,18,19$ & $1,2,9,12,13,15,21$ & $3,4,5,8,14,17,20$ \\
\hline
\end{tabular}

The data were analyzed using SPSS. Between the two schools, significance was tested using Ttests for independent samples (after finding significance using Levene's Test for equality of variances). Between the three resources significance was tested using T-tests for dependent samples (after determining significant Pearson correlations). Significance was defined as $p<0.05 / 3$ since the comparison was between two out of three groups (FDR correction).

\section{Findings}

Overall, the average interest level in all the questions was $3.38 \pm 1.35$ (on a 1-5 scale). The average interest level in all the questions on the topic of "space" was $3.48 \pm 0.41$, higher by 0.2 than the topic of "nutrition", which was $3.28 \pm 0.23$ (not a significant difference).

No significant differences for gender were found in students' interest level (Table 3).

Table 3: Students' interest level on all the questions, between genders and schools

\begin{tabular}{|l|l|c|c|c|}
\hline \multicolumn{2}{|l|}{} & Average & $\begin{array}{c}\text { Standard } \\
\text { Deviation }\end{array}$ & Significance \\
\hline $\begin{array}{l}\text { Total average students' } \\
\text { interest level }\end{array}$ & 3.38 & 0.34 & \\
\hline \multirow{2}{*}{ Gender } & Male (n=56) & 3.42 & 0.94 & \multirow{2}{*}{ n.s. } \\
\cline { 2 - 4 } & Female (n=57) & 3.34 & 0.8 & \multirow{2}{*}{$\begin{array}{c}\text { Significance at } \\
\text { p<0.05 }\end{array}$} \\
\hline \multirow{2}{*}{ School } & A (n=66) & 3.7 & 0.76 & \multirow{2}{*}{0.81} \\
\cline { 2 - 4 } & B (n=47) & 2.93 & & \\
\hline
\end{tabular}

The most popular question for the topic of "space" was "Will a black hole eventually swallow the Earth?" (4.21), originally asked by a student, and the least popular question was "What objects are in the solar system and how are they similar/different from each other?" originating from the textbook (2.82).

In the topic of "nutrition", the most popular question was "Is it possible to fry an egg on the sidewalk if it's hot enough?"(3.59) taken from the open resource, and the least popular question was " Is there such a thing as unhealthy food?" (2.86), originally asked by a student. 


\section{Table 4: Fifth-grade students' average interest level in 21 questions} on the topic "space", ordered by their popularity

\begin{tabular}{|c|c|c|c|}
\hline Question (Question number) & Source & Average & $\begin{array}{l}\text { Standard } \\
\text { Deviation }\end{array}$ \\
\hline Will a black hole eventually swallow the Earth? (8) & Students & 4.25 & 1.29 \\
\hline Will the Sun disappear some day? (17) & Students & 4.20 & 1.17 \\
\hline What space research technologies will be available in a hundred years? (18) & Textbook & 3.99 & 1.18 \\
\hline What is the moon made of? (4) & Students & 3.94 & 1.21 \\
\hline How different would the world be if the Earth had no moon? (9) & Open resource & 3.87 & 1.20 \\
\hline Why there is no oxygen on other planets? (15) & Open resource & 3.81 & 1.29 \\
\hline What do you see on the moon? (16) & Textbook & 3.80 & 1.23 \\
\hline Could there be life on Europa (one of the moons of Jupiter)? (1) & Open resource & 3.65 & 1.17 \\
\hline Way does the Earth rotate around the Sun and what caused it to start? (2) & Open resource & 3.57 & 1.27 \\
\hline How long does it take to reach space from Earth? (20) & Students & 3.56 & 1.30 \\
\hline What is the Sun? (3) & Students & 3.27 & 1.32 \\
\hline What is the largest planet? (12) & Open resource & 3.27 & 1.33 \\
\hline Are there other planets aside from the Earth in the universe? (13) & Open resource & 3.25 & 1.40 \\
\hline What is the length of the year on Venus, Mars, Earth and Mercury? (7) & Textbook & 3.20 & 1.27 \\
\hline Are the stars that we see in the sky reflecting light or emitting light? (21) & Open resource & 3.20 & 1.38 \\
\hline Why is Mars called "the red planet"? (14) & Students & 3.17 & 1.32 \\
\hline What was Michael Collins' job on Apollo 11? (6) & Textbook & 3.12 & 1.28 \\
\hline What is the structure of the solar system? (10) & Textbook & 3.12 & 1.33 \\
\hline Who was the first person to reach space? (5) & Students & 3.11 & 1.45 \\
\hline $\begin{array}{l}\text { Is there a relationship between the distance of a planet from the sun and the } \\
\text { length of its year? (19) }\end{array}$ & Textbook & 3.04 & 1.37 \\
\hline $\begin{array}{l}\text { What objects are in the solar system and how they are similar/different from each } \\
\text { other? (11) }\end{array}$ & Textbook & 2.82 & 1.33 \\
\hline
\end{tabular}

*The shaded area indicates below average students' interest level.

\section{Table 5: Fifth-grade students' average interest level in 21 questions on the topic "nutrition", ordered by their popularity}

\begin{tabular}{|c|c|c|c|}
\hline Question (Question number) & Source & Average & $\begin{array}{l}\text { Standard } \\
\text { Deviation }\end{array}$ \\
\hline Is it possible to fry an egg on the sidewalk if it's hot enough? (25) & Open resource & 3.59 & 1.30 \\
\hline What kind of food is digested the fastest? (42) & Students & 3.59 & 1.41 \\
\hline $\begin{array}{l}\text { In the desert there are lizards that do not drink at all. Where do they get } \\
\text { the water they need to live? (33) }\end{array}$ & Textbook & 3.58 & 1.37 \\
\hline Why are we thirsty after we eat something sweet? (34) & Open resource & 3.57 & 1.29 \\
\hline What will happen if I only eat meat all week? (32) & Students & 3.55 & 1.36 \\
\hline Why do potatoes and apples turn brown after you cut them? (37) & Open resource & 3.46 & 1.35 \\
\hline Does eating at night cause obesity more than eating during the day? (35) & Open resource & 3.44 & 1.39 \\
\hline Why do we and all living things need water? (41) & Textbook & 3.44 & 1.37 \\
\hline $\begin{array}{l}\text { Why do we look for water and not for oxygen on planets - is water } \\
\text { really necessary for life? ( } 30)\end{array}$ & Students & 3.43 & 1.31 \\
\hline What would happen if the food we eat didn't dissolve in water? (28) & Textbook & 3.28 & 1.28 \\
\hline Why does food spoil and how does it happen? (36) & Open resource & 3.27 & 1.42 \\
\hline How much do we need to drink every day? (40) & Students & 3.20 & 1.36 \\
\hline Does sugar damage our stomach? (23) & Students & 3.19 & 1.32 \\
\hline $\begin{array}{l}\text { What would happen if the esophagus was made of cartilage rings like } \\
\text { the trachea? (24) }\end{array}$ & Textbook & 3.19 & 1.27 \\
\hline Does all the food we eat and don't vomit stay in the body? (38) & Students & 3.18 & 1.32 \\
\hline Where in the digestive system is the food absorbed? (27) & Textbook & 3.05 & 1.37 \\
\hline How do we digest our food? (22) & Students & 3.04 & 1.26 \\
\hline What characteristics of water in liquid form are important for life? (26) & Textbook & 3.04 & 1.21 \\
\hline Is the color of wine related to the color of grapes? (31) & Open resource & 3.00 & 1.38 \\
\hline What are the food groups? (39) & Textbook & 2.91 & 1.26 \\
\hline Is there such a thing as unhealthy food? (29) & Students & 2.86 & 1.34 \\
\hline
\end{tabular}

*The shaded area indicates below average students' interest level. 
Tables 4 and 5 present the average and standard deviation (SD) of interest levels for each of the 42 questions, ranked according to their popularity. The original question structure was preserved while translating from Hebrew to English in order to present the original questions as accurately as possible. This results in less than perfect English grammar, to mimic the original Hebrew question.

\section{Differences in Interest Level across the Three Sources}

A significant difference $(\mathrm{p}<0.016)$ in students' average interest level was found the between textbook questions, open-resource questions, and student questions.

On the topic of "space" (Figure 3a), the interest level in the textbook questions was significantly lower than the two other resources. The interest level in students' questions was significantly higher than the open-resource questions. On the topic of "nutrition" (Figure 3b), the interest level in open-resource questions was significantly higher than the two other resources.
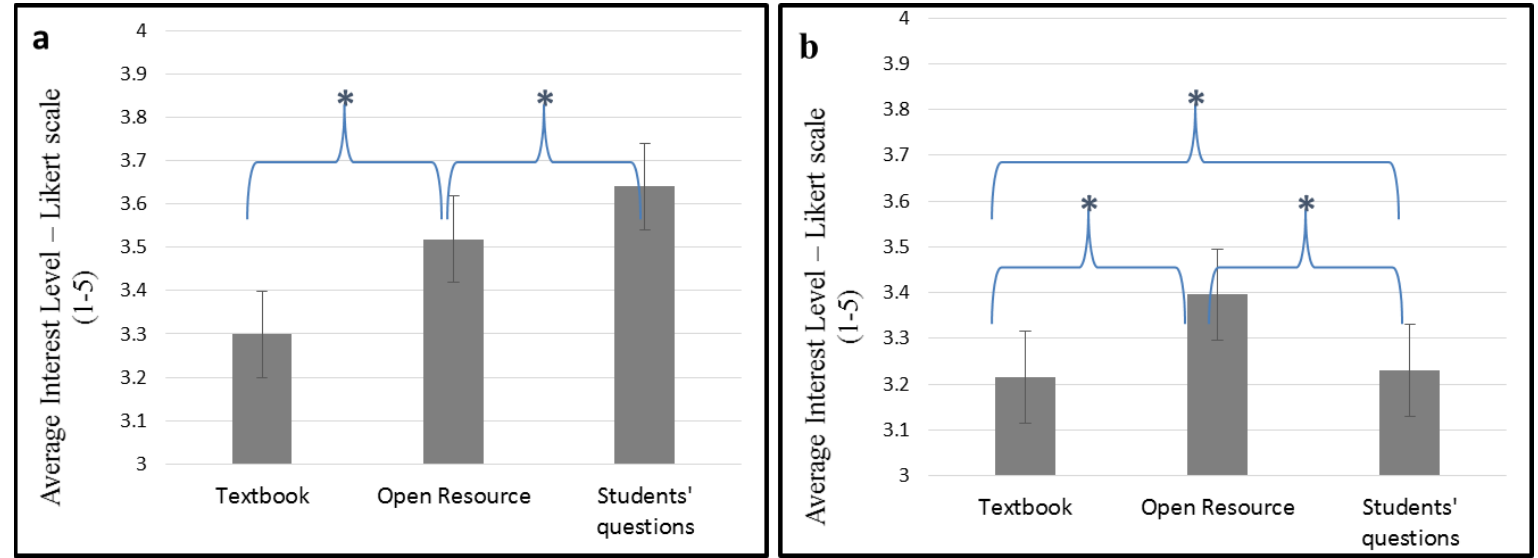

Figure 3. Students' average interest level on questions from different sources for the "space" (a) and "nutrition" (b) topics

* indicates significance at $\mathrm{p}<0.05 / 3$

\section{Differences in Interest Level between Schools}

There was a significant difference $(\mathrm{p}<0.05)$ in students' average interest level between the schools (Table 1). The average interest level on almost all the questions in school A (which is characterized by a lower achievement level) was higher than in school B.

Despite the differences in overall interest level, a high correlation between schools $(r=0.84)$ was found with regard to the questions students found interesting (Figure 4). It is interesting to note that the correlation between schools on the topic of space $(\mathrm{r}=0.93)$ was much higher than the nutrition topic $(r=0.68)$, as seen in Figure $4 a$ and $4 b$.

The inverse correlation between achievement and interest at the school level mirrors findings from PISA 2006 which indicated "a tendency for students in low-performing countries to show relatively high levels of interest in science, with students in high-achieving countries showing relatively lower levels of interest" (Bybee \& McCrae, 2011, p. 17). 


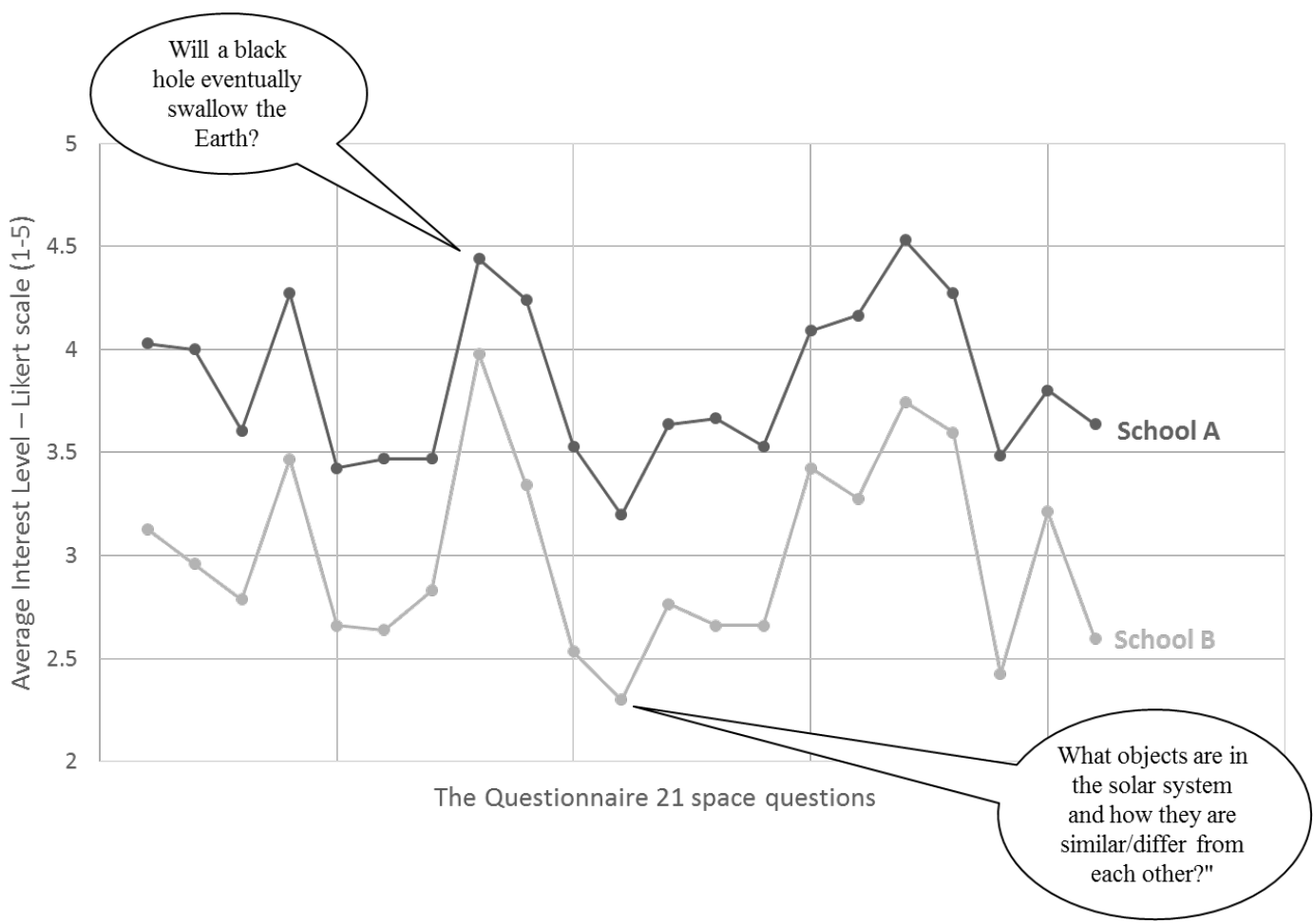

Figure 4a. Comparison of students' average interest level on the space topic in the two schools $(r=0.93)$

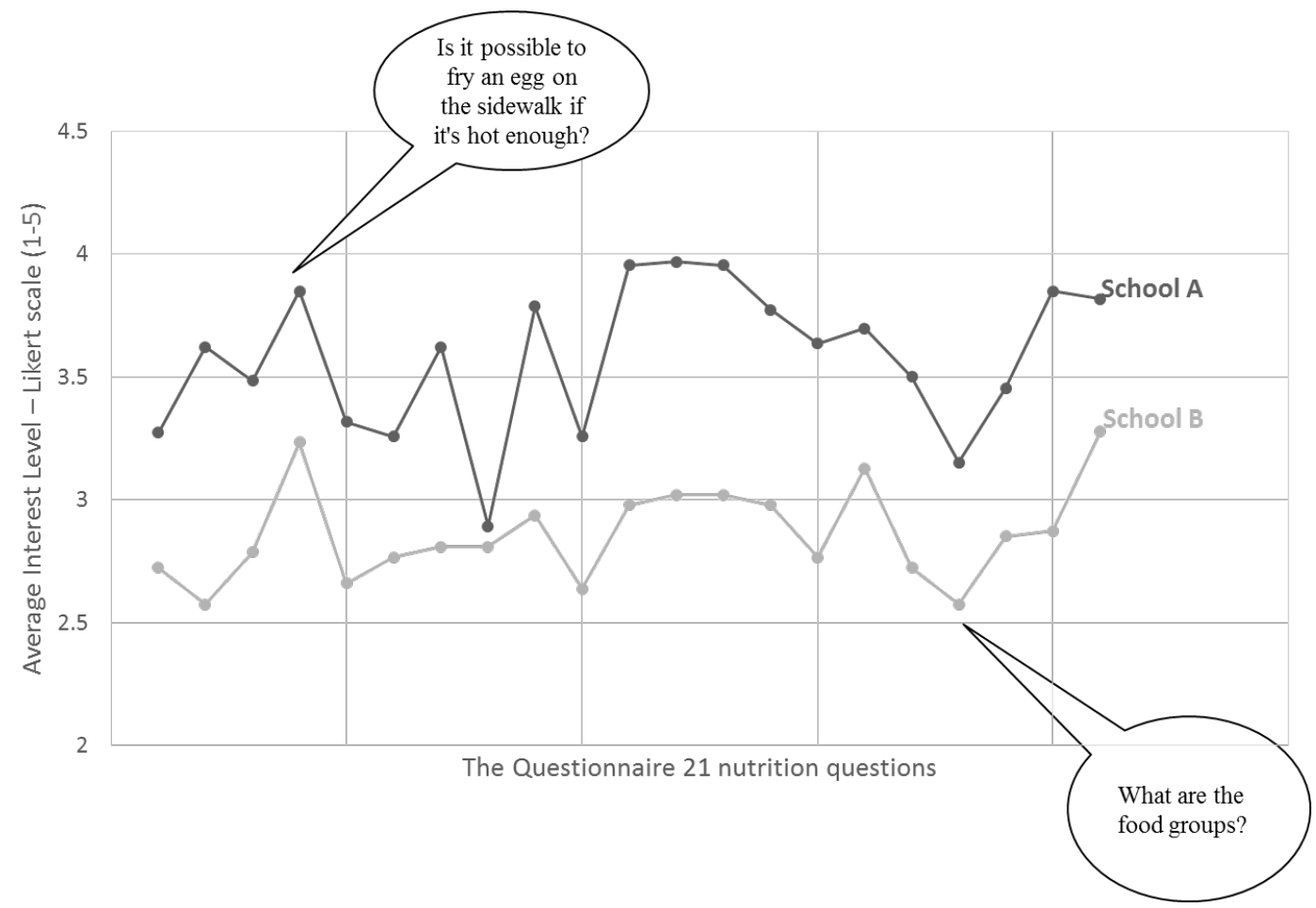

Figure 4b. Comparison of students' average interest level on the nutrition topic in two schools $(r=0.68)$ 


\section{Research Limitations}

This study has several limitations. The main limitation was the small sample of questions used from each database. The questionnaire had only 14 questions from each source, which is less than $5 \%$ of the 868 collected questions. Therefore, the results could have been different if other questions had been included in the questionnaire or if other topics had been used.

Another limitation of this study was the small number of participants and the lack of diversity among participants. The two schools were from the same area and the same sector. Moreover, all the participants were from the same grade level. Thus, generalization is limited. Future studies with a larger and more diverse sample could lead to greater generalizability of the findings. Furthermore, generalization is limited to similar Q\&A sites and not to all kinds of OER.

Furthermore, although the questions were randomly ordered, the questionnaire was administrated in one version alone; thus the order might have influenced the results due to fatigue.

\section{Discussion}

Could questions sent to an Ask-An-Expert OERs serve as indicators for students' interest in science? This question was examined as part of a broader study aimed at utilizing Web 2.0 technologies to incorporate the "student voice" into mainstream science teaching. The findings indicate the relative popularity in many of the questions sent by a motivated few to these OERs.

The high correlation between students' interest levels in specific questions from two different schools tends to support generalization. This finding is consistent with previous studies that found similarities across student questions. For example, Sperduti, Crivellaro, Rossi, and Bondioli (2012), who collected questions on the topic of the brain from 508 Italian students, reported that questions such as "what else the brain do?" and "how does the brain work?" were frequently asked by the students. Moreover, Baram-Tsabari and Yarden (2005), who examined more than 1600 questions sent to a series of television programs also found repetitive questions, such as "who invented the computer?" which was tabulated 26 times, and patterns of questions, such as "which is the biggest/fastest/strongest/smallest animal" which occurred 46 times.

These frequently asked questions support the potential of an "online shadow curriculum" by using Q\&A databases as bridges between curricular requirements and students' interests. This online repertoire of interesting Q\&As and their curricular relevance may remedy the problem identified by teachers: incorporating students interests into their teaching requires much work in collecting and researching students' questions (Hagay \& Baram-Tsabari, 2015).

Although the findings described here point to the validity of using questions sent to open learning resources as indicators of students' interests, it is still important to ask: Do the questions asked in this paper really reflect the "student voice"?

From a theoretical point of view, the answer might be "no", as Cook-Sather (2006, p. 363) claims: “...'Student voice' as a term asks us to connect the sound of students speaking not only with those students experiencing meaningful, acknowledged presence but also with their having the power to influence analyses of, decisions about, and practices in schools." However, from a practitioner's point of view, the answer might be "yes", since the findings point that science questions that were sent by motivated individuals to Ask-An-Expert website are interesting to a broader students" audience. This might contribute to bringing the "student voice" into science class in practice by using OERs, not only as an educational resource but also as a tool for reflecting and addressing the interests of wider student audiences.

This ambiguity points to a potential contribution of this research: Many studies have addressed the changes that need to be made in education in the digital era. For example, some are exploring 
new models for teaching, such as the flipped class, some have suggested new disciplines, such as programming, and yet others point to skills that should be included in the curriculum, such as digital literacy. This study documents yet another affordance of Web 2.0 technologies in education: technology as a means of identifying student interests to promote the "student voice" in science education.

\section{Acknowledgments}

This research was supported by the I-CORE Program of the Planning and Budgeting Committee and The Israel Science Foundation (1716/12).

\section{References}

Ainley, M., Hidi, S., \& Berndorff, D. (2002). Interest, learning, and the psychological processes that mediate their relationship. Journal of Educational Psychology, 94(3), 545-561.

Baram-Tsabari, A. (2015). Promoting information seeking and questioning in science. In A. Renninger (Ed.), Interest, the self, and K-16 mathematics and science learning (pp. 135-152). AERA Handbook.

Baram-Tsabari, A., Sethi R. J., Bry L., \& Yarden, A. (2006). Using questions sent to an Ask-A-Scientist site to identify children's interests in science. Science Education, 90(6), 1050-1072.

Baram-Tsabari, A., \& Yarden, A. (2005). Characterizing children's spontaneous interests in science and technology. International Journal of Science Education, 27(7), 803-826.

Baram-Tsabari, A., \& Yarden, A. (2007). Interest in biology: A developmental shift characterized using self-generated questions. The American Biology Teacher, 69(9), 546-554.

Bybee, R., \& McCrae, B. (2011). Scientific literacy and student attitudes: Perspectives from PISA 2006 science. International Journal of Science Education, 33(1), 7-26.

Center for Science and Technology. (2008). Science and technology for the $5^{\text {th }}$-grade. Tel-Aviv University, Tel-Aviv: Ramot Publishing.

Chin, C., \& Osborne, J. (2008). Students' questions: A potential resource for teaching and learning science. Studies in Science Education, 44(1), 1-39.

Clements, K. I., \& Pawlowski, J. M. (2012). User-oriented quality for OER: Understanding teachers' views on re-use, quality, and trust. Journal of Computer Assisted Learning, 28(1), 4-14.

Cohen, A., Kalimi, S., \& Nachmias, R. (2013). The use of digital repositories for enhancing teacher pedagogical performance. Interdisciplinary Journal of E-Learning and Learning Objects, 9, 201-218. Retrieved from http://www.ijello.org/Volume9/IJELLOv9p201-218Cohen0861.pdf

Cook-Sather, A. (2006). Sound, presence, and power: "Student voice" in educational research and reform. Curriculum Inquiry, 36(4), 359-390.

Davie, R., \& Galloway, D. (1996). The voice of the child in education. In R. Davie \& D. Galloway (Eds.), Listening to children in education, (pp. 2-14). London: David Fulton.

Dewey, J. (1902). The school and society and the child and the curriculum. Chicago: University of Chicago Press.

Dewey, J. (1916). Democracy and education. NY: The Free Press.

Dillon, J. T. (1988). The remedial status of student questioning. Journal of Curriculum Studies, 20,197210.

Grace, M. (1999). When students create curriculum. Educational Leadership, 57(3), 49-52.

Hagay, G., \& Baram-Tsabari, A. (2011). A shadow curriculum: Incorporating students' interests into the formal biology curriculum. Research in Science Education, 41(5), 611-634. 
Hagay, G., \& Baram-Tsabari, A. (2015). A strategy for incorporating students' interests into the highschool biology classroom. Journal of Research in Science Teaching. DOI: 10.1002/tea.21228

Hagay, G., Baram-Tsabari, A., Ametller, J., Cakmakci, G., Lopes, B., Moreira, A., \& Pedrosa-de-Jesus, H. (2013). The generalizability of students' interests in biology across gender, country and religion. Research in Science Education, 43(3), 895-919.

Harper, F. M., Raban, D., Rafaeli, S., \& Konstan, J. A. (2008, April). Predictors of answer quality in online Q\&A sites. In Proceedings of the SIGCHI Conference on Human Factors in Computing Systems (pp. 865-874). ACM.

Hennessy, E. (1999). Children as service evaluators. Child and Adolescent Mental Health, 4(4), 153-161.

Hilton, J. L., Wiley, D., \& Johnson, A. (2010). The four 'R's of openness and ALMS analysis: Frameworks for open educational resources. Open Learning: The Journal of Open, Distance and e-Learning, 25(1), $37-44$.

Hylén, J. (2006). Open educational resources: Opportunities and challenges. Proceedings of Open Education, 49-63.

Israeli Ministry of Education (2015). (in Hebrew). Retrieved October 15, 2015, from http://davidson.weizmann.ac.il/sites/davidson.lxst.codeoasis.com/files/imce/misrad-chinuch 0.pdf

Israeli Ministry of Finance (2008). (in Hebrew). Socio-Economic index of local authorities. Retrieved December 10, 2012, from http://www.cbs.gov.il/publications13/1530/pdf/tab01_01.pdf

Jenkins, E. W. (2006). The student voice and school science education. Studies in Science Education, 42(1), 49-88.

Jidesjö, A., Oscarsson, M., Karlsson, K-G., \& Strömdahl, H. (2009). Science for all or science for some: What Swedish students want to learn about in secondary science and technology and their opinions on science lessons. Nordina, 5(2), 213-229.

Kain, D. J. (2003). Teacher-centered versus student-centered: Balancing constraint and theory in the composition classroom. Pedagogy, 3(1), 104-108.

Kanwar, A., Uvalić-Trumbić, S., \& Butcher, N. (2011). A basic guide to open educational resources (OER). Vancouver: Commonwealth of Learning; Paris: UNESCO.

Levin, B. (2000). Putting students at the centre of education reform. Journal of Educational Change, 1(2), 155-172.

Mitra, D. L. (2003). Student voice in school reform: Reframing student-teacher relationships. McGill Journal of Education, 38(2), 289-304.

Mitra, D. (2004). The significance of students: Can increasing "student voice" in schools lead to gains in youth development? The Teachers College Record, 106(4), 651-688.

Murray, I., \& Reiss, M. (2005). The student review of the science curriculum. School Science Review, 87(318), 83-93.

Renninger, K. A., \& Hidi, S. (2011). Revisiting the conceptualization, measurement, and generation of interest. Educational Psychologist, 46(3), 168-184.

Sperduti, A., Crivellaro, F., Rossi, P. F., \& Bondioli, L. (2012). “Do octopuses have a brain?” Knowledge, perceptions and attitudes towards neuroscience at school. PLoS ONE, 7(10), e47943.

Student voice. (2013, December 20). In S. Abbott (Ed.), The glossary of education reform. Retrieved from http://edglossary.org/student-voice/

Swarat, S., Ortony, A., \& Revelle, W. (2012). Activity matters: Understanding student interest in school science. Journal of Research in Science Teaching, 49(4), 515-537. 
Swirski, H., \& Baram-Tsabari, A. (2014). Bridging the gap between the science curriculum and students' questions: Comparing linear vs. hypermedia online learning environments. Interdisciplinary Journal of E-Learning and Learning Objects, 10, 153-175. Retrieved from http://www.ijello.org/Volume10/IJELLOv10p153-175Swirski0898.pdf

Tai, R. H., Liu, C. Q., Maltese, A. V., \& Fan, X. (2006). Planning early for careers in science. Science, 312(5777), 1143-1144.

Toshalis, E., \& Nakkula, M. J. (2012). Motivation, engagement, and student voice. Education Digest, 78(1), 29-35.

Weller, M. (2010). Big and little OER. Paper presented at OpenED2010, Seventh Annual Open Education Conference, 2-4 November 2010, Barcelona, Spain.

Wiley, D. (2009). Impediments to learning object reuse and openness as a potential solution. Revista Brasileira de Informática na Educação, 17(3).

Xie, Y., \& Reider, D. (2014). Integration of innovative technologies for enhancing students' motivation for science learning and career. Journal of Science Education and Technology, 23, 370-380.

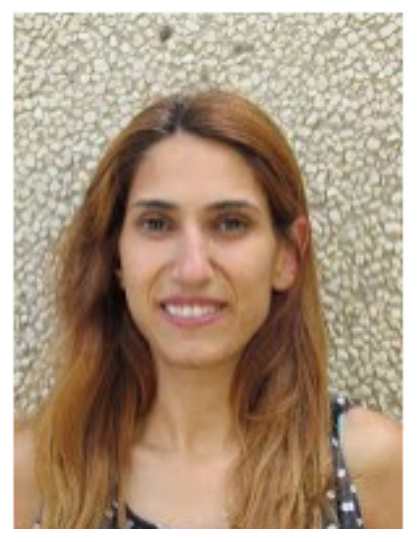

\section{Biographies}

Hani Swirski completed her BSc and MEd at the Technion - Israel Institute of Technology at the Faculty of Education in Science and Technology in Physics education. From 2005 to 2013, she worked at an elementary school in the northern part of Israel, teaching science. During the last two years, she trained teachers to use ICT tools in teaching while maximizing their pedagogical value. Now she is a $\mathrm{PhD}$ student in the Faculty of Education in Science and Technology under the supervision of Prof. Ayelet Baram-Tsabari. Her research focuses on integrating student voice into the science curriculum using online learning environment, which is based on students' questions.

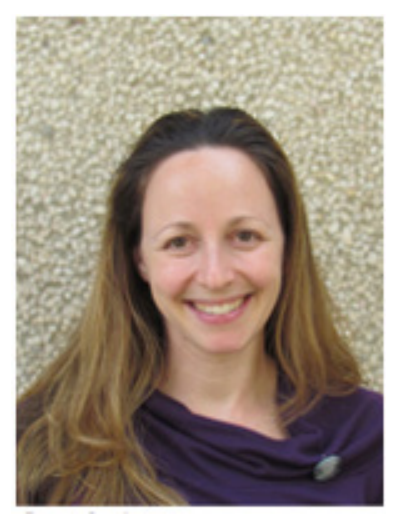

Ayelet Baram-Tsabari is an Assistant Professor at the Technion Israel Institute of Technology, and head of the Biology Education and Science Communication research groups at the Faculty of Education in Science and Technology. She is a member of the Learning in a Networked Society (LINKS) Israeli center of Research Excellence (ICORE).

Her main research interests are in bridging science education and science communication scholarship, including identifying peoples' interests in science and building on these authentic interests to teach and communicate science in more meaningful and personally relevant ways. 